\title{
A Wearable Iron-Based Implant as an Intramedullary Nail in Tibial Shaft Fracture of Sheep
}

\author{
Sitaria F. Siallagan, ${ }^{1}$ Marzuki Silalahi, ${ }^{2}$ Arief Boediono, ${ }^{1}$ \\ Sri Estuningsih, ${ }^{1}$ and Deni Noviana $\mathbb{1}^{1}$ \\ ${ }^{1}$ Bogor Agricultural University (IPB), Bogor 16680, Indonesia \\ ${ }^{2}$ Center for Science and Technology of Advanced Materials (BATAN), Tangerang 15314, Indonesia \\ Correspondence should be addressed to Deni Noviana; deni@ipb.ac.id
}

Received 5 October 2018; Revised 25 December 2018; Accepted 28 January 2019; Published 3 March 2019

Guest Editor: Muhammad A. Fareed

Copyright (C) 2019 Sitaria F. Siallagan et al. This is an open access article distributed under the Creative Commons Attribution License, which permits unrestricted use, distribution, and reproduction in any medium, provided the original work is properly cited.

\begin{abstract}
A stable repaired fracture is the key factor responsible for the recovery of a damaged bone. The iron-based implant is one of the biodegradable metals that have been proven safe as a fracture fixation device. The objective of our experimental approach was to examine the potential of the iron-based implant as a biodegradable metal in tibia shaft fracture in sheep chronically. The samples used for this experiment were iron-based and stainless steel implants. Each had a diameter of $5 \mathrm{~mm}$. These samples were analyzed through 3 phases which are material characterization, in vitro and in vivo examination. The samples were examined using a scanning electron microscope with energy dispersive spectrometer and X-ray diffraction. Based on the analysis carried out, the samples contained $90,02 \%$ and $60,81 \%$ Fe for iron-based implant and stainless implant, respectively. Both implants maintained high viability when being in contact with calf pulmonary artery endothelial cells, indicating that both implants had a minimum response to the cell in a hemocytometer and methyl tetrazolium (MTT) assay. The systemic effect of the implants was observed using hematology and blood chemistry examination. Data collection also shows that both implants also had a minimum response to the erythrocytes, leucocytes, blood chemistry, and blood mineral during the period of observation. Therefore, it could be concluded that the ironbased implant is tolerable for a period of 9 months. It also has the potential to be used as a biodegradable orthopedic implant.
\end{abstract}

\section{Introduction}

The main factor that influenced the bone healing is a stable fracture repaired. While the structure of the bone healing is unstable, the intramedullary nail has long been used as a fracture fixation device for tibia shaft fracture. The intramedullary nail is still being used in the veterinary field as needed $[1,2]$. The widespread use of stainless steel, titanium, and other nondegradable metal materials is still regarded as the golden standard for the orthopedic implant. This is due to the fact that they are the most applied materials even if more research is still carried out $[3,4]$.

Nondegradable metals have been used for decades as orthopedic implants for their high strength, ductility, tenacity, hardness, fracture toughness, corrosion resistance, formability, and biocompatibility [5]. Due to the nondegradable metals implant characterizations, a second surgery to remove those implants when the healing process has been completed has proven to be necessary in several cases [6]. Absorbable metals such as magnesium, zinc, and iron are expected to corrode gradually in vivo by an appropriate host response and then dissolve completely upon assisting bone healing [7]. Thus, the requirement of the biodegradable metal implant has increased the research for the iron-based orthopedic implant as a degradable metallic material [8].

Iron is a normal component of heme and nonheme enzymes and proteins [9]. Although the use of iron as a bone implant is still debated due to its toxicity, iron deficiency could lead to a variety of disorder [10]. Iron has attractive mechanical properties, approaching those of stainless steel. Due to the formation of a complex iron phosphate layer, iron has a low degradation rate [11] and is required in little quantity [12]. A lot of iron-based implants research has been 
conducted, but just a few of them discussed the potential of the iron-based implant in a clinical study chronically.

Numerous orthopedic research has been conducted using sheep as an animal model due to the physical stature and weight $[13,14]$. Several orthopedic implants have also been observed in the sheep $[15,16]$. However, just a few of these researches observed the iron-based systemic responses as an orthopedic implant. Therefore, the objective of this study is to examine the potential of the iron-based implant as a biodegradable metal in tibia shaft fracture in sheep chronically.

\section{Materials and Methods}

2.1. Material Preparation. Iron-based implant (BjPT 6, Tunggal Jaya Steel ${ }^{\circledR}$, Indonesia) and stainless steel implant (Steinmann Pin, Sklar ${ }^{\circledR}$, USA) with $5 \mathrm{~mm}$ diameter were cut to $1 \mathrm{~mm}$ length for material characterization and in vitro examination and were adapted to the tibia bone length size of sheep for in vivo examination. All the implants were sterilized using dry autoclave $121^{\circ} \mathrm{C}$ for 6 hours and UV ray for 1 hour before being used in this study.

2.2. Material Characterization. Surface morphology and metal composition of the implants were observed using a scanning electron microscope (SEM) with an energy dispersive spectrometer (JSM-6510LA, JEOL ${ }^{\circledR}$ ) to observe the microstructure of the implants. Iron-based and stainless steel implants were polished using sandpaper until grid \# 2000 then etched by using nital (Nital Etch 2\%, USA). SEM analysis was taken at an accelerating energy rate of $20 \mathrm{keV}$. X-ray diffraction with $\mathrm{CuK} \alpha$ radiation (Empyrean, PANalytical ${ }^{\circledR}$ ) was done after the implants were polished until grid $\# 1500$ for phase identification

2.3. In Vitro Examination. The viability of the cell was examined using hemocytometer and MTT assay. Haemocytometer was used to observe the interference of the implant directly to the cell, and the MTT assay was used to observe the interference of the degradation solution of the implant to the cell. For direct method, the calf pulmonary artery endothelial cell was cultured 10.000 cells per plate in Dulbecco's modified Eagle's medium (DMEM, Sigma-Aldrich) and incubated (Binder, Germany) for 24 hours in $5 \% \mathrm{CO}_{2}$ and $37^{\circ} \mathrm{C}$. Thereafter, an implant with $1 \mathrm{~mm}$ of thickness and $5 \mathrm{~mm}$ of diameter was put on the surface of the cells and incubated for 76 hours in $5 \% \mathrm{CO}_{2}$ and $37^{\circ} \mathrm{C}$. Half of the media culture was removed, then the rest of it was poured into a $15 \mathrm{ml}$ centrifuge tube (Corning, USA) and centrifuged using flexpin bench-top centrifuge (Tomy, Japan) $500 \mathrm{~g}$ for $5 \mathrm{~min}$. The supernatant was removed and the cells were counted using hemocytometer. For the indirect method, all of the implants with $3 \mathrm{~mm}$ of thickness and $5 \mathrm{~mm}$ of diameter were immersed in low glucose DMEM for 7 and 14 days. One hundred $\mu$ l of the immersed solution and $100 \mu \mathrm{l}$ of low glucose DMEM were dripped into 96 plates well (Corning, USA). Ten $\mu 15 \mathrm{mg} / \mathrm{ml}$ MTT stock solution (Sigma Aldrich, USA) was aspirated to each well and then incubated for 4 hours in $37^{\circ} \mathrm{C}$ and $5 \% \mathrm{CO}_{2}$ before the supernatant was aspirated. The optical density was read using a microplate reader at $565 \mathrm{~nm}$.

2.4. In Vivo Examination. All of the procedures were approved by animal care and use committee of Veterinary Teaching Hospital of Bogor Agricultural University (ACUC RSHP FKH IPB) number 12-2015 RSHP FKH-IPB. Eight male sheep were divided into 2 groups of iron-based and stainless steel implant. Implant with $5 \mathrm{~mm}$ of diameter and a length that adapted to the length of tibia bone of the sheep was inserted into the left tibia bone intramedullary.

Before implantation, all of the sheep were injected with an antitetanus serum (Biostat $1.5^{\circledR}$, Biopharma, Indonesia). The implants were implanted under general anesthesia. Anesthesia was induced using ketamine and xylazine combination intravenously (3 mg/kg BB Ketamin ${ }^{\circledR}$, Kepro BV, Netherland and $0.1 \mathrm{mg} / \mathrm{kg} \mathrm{BB}, \mathrm{Xyla}^{\circledR}$, Interchemie, Holland) and maintained with ketamine intravenously ( $3 \mathrm{mg} / \mathrm{kg} \mathrm{BB})$. Prior to surgery, the surgical site was shaved and iodine solution was applied. A longitudinal skin incision was made to access the lateral diaphysis of the tibia. A middiaphysis tibia osteotomy was performed, stabilizing with the intramedullary bone implant. The wound was closed in three layers, i.e., the fascial, subcutaneous, and skin layers separately. General antibiotics such as gentamycin $\left(3 \mathrm{mg} / \mathrm{kg} \mathrm{BB}\right.$, Bio-genta ${ }^{\circledR}$, Biopharchemie, Vietnam) and amoxicillin long-acting (20 $\mathrm{mg} / \mathrm{kg} \mathrm{BB}$, Intramox-150 $\mathrm{LA}^{\circledR}$, Interchemie, Holland) were administered intramuscularly to prevent postsurgery secondary infection for 1 week. Tramadol $(2 \mathrm{mg} / \mathrm{kg} \mathrm{BB}$, Tramadol $^{\circledR}$, PT Indofarma, Indonesia) was also administered intravenously as an analgesic for 2 weeks. Blood sampling was performed every month until month 9 after implantation on the jugular vein to analyze the systemic effect of the implants.

2.5. Data Analytics. Data were analyzed using analysis of variance (ANOVA) and post hoc DUNCAN with the $P$ value of $\mathrm{P} \leq 0.05$ as statistically significant.

\section{Results and Discussion}

3.1. Material Characterization. Figure 1 shows the surface morphology of (a) iron-based implant and (b) stainless steel implant. An iron-based implant is seen with small holes and rough surface, while stainless steel implant is well smoothened with smaller holes. According to the SEM and EDS analysis, the iron-based implant contained 90,02\% $\mathrm{Fe}$ (Figure 1(c)) and the stainless steel implant contained 60,81\% Fe; $17,13 \% \mathrm{Cr} ; 13,14 \% \mathrm{Ni} ; 2,87 \% \mathrm{Mo}$, and 1,31\% Mn (Figure $1(\mathrm{~d})$ ). Figures $1(\mathrm{e})$ and $1(\mathrm{f})$ show a plot of observed XRD pattern for sample iron-based and stainless steel implant. The diffraction patterns show the similarity to iron-based steel as indicated by Silalahi et al. [17] and to stainless steel as indicated by Dadfar et al. [18].

3.2. In Vitro Examination. Calf pulmonary artery endothelial cell viability of iron-based and stainless steel implant is seen in Figure 2. In hemocytometer examination, both implants had maintained high cell viability of CPAE (Figure 2(a)) during the 3-day incubation time. An insignificant difference 


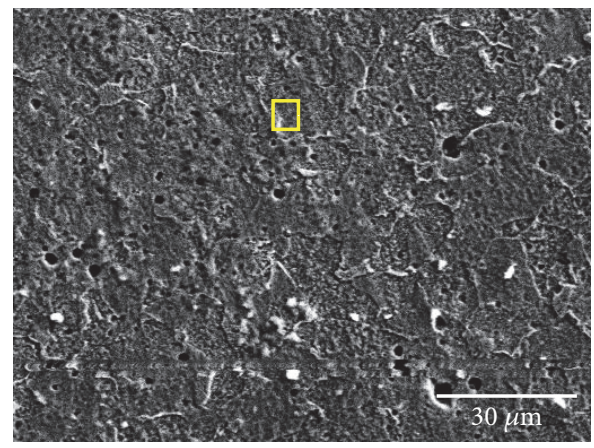

(a)

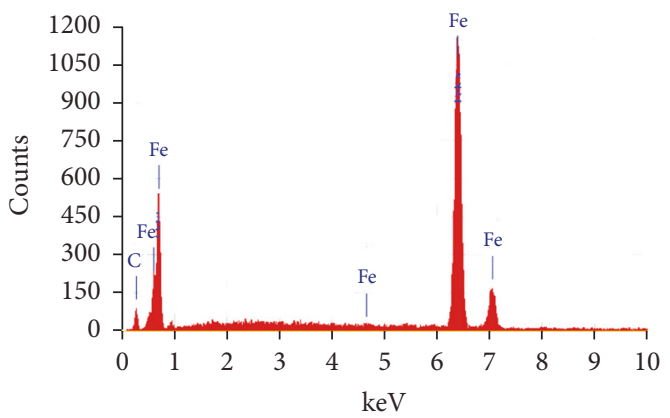

SAF Method Standardless Quantitative Analysis Fitting coefficient : 0.2567

$\begin{array}{lc}\text { Element } & \text { Mass (\%) } \\ \text { C K } & 9.48 \\ \text { Fe K } & 90.52 \\ \text { Total } & 100.00\end{array}$

(c)

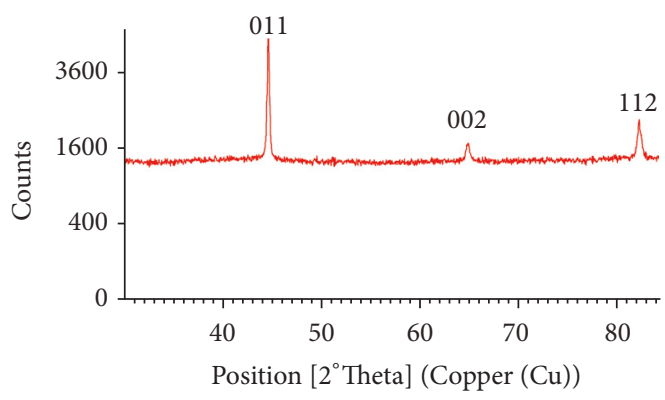

(e)

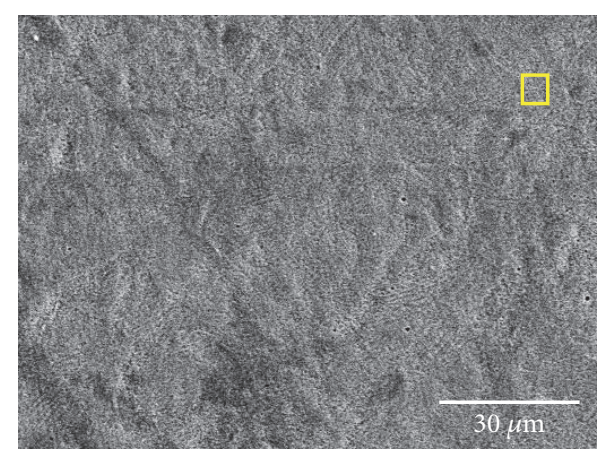

(b)

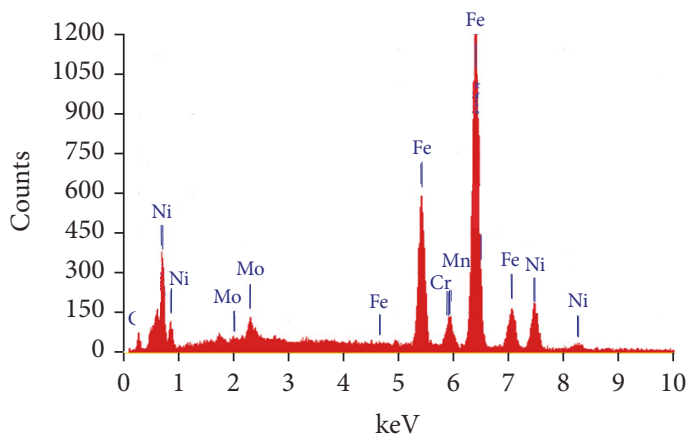

SAF Method Standardless Quantitative Analysis Fitting coefficient : 0.2567

$\begin{array}{lclc}\text { Element } & \text { Mass (\%) } & \text { Element } & \text { Mass (\%) } \\ \text { C K } & 4.74 & \text { Fe K } & 60.81 \\ \text { Cr K } & 17.13 & \text { Ni K } & 13.14 \\ \text { Mn K } & 1.31 & \text { Mo L } & 2.87 \\ & & \text { Total } & 100.00\end{array}$

(d)

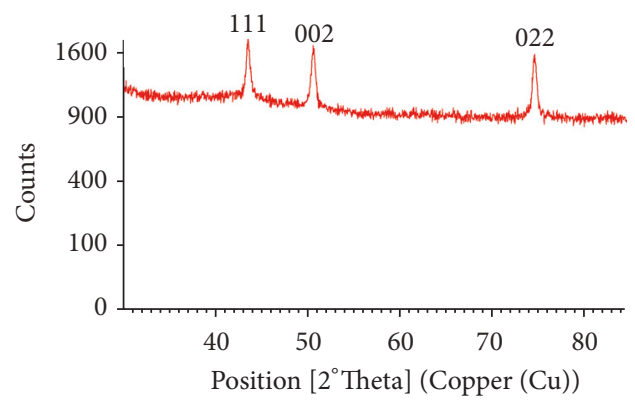

(f)

FIGURE 1: Surface scanning electron microscopy micrographs of sample (a) overview of iron-based implant, (b) overview of stainless steel implant (1000x mag), (c) EDS spectra of iron-based, and (d) EDS spectra of stainless steel, (e) X-ray diffraction of iron-based, and (f) X-ray diffraction of stainless steel implant.

( $p>0.05$ ) was observed in both groups, indicating that these implants did not stimulate excessive inhibition in cell culture. Figure 2 also shows that the cell viability of ironbased implant was lower than the cell viability of stainless steel implant using hemocytometer (Figure 2(a)) and MTT assay (Figure 2(b)). Iron is a chemical element that is active in the fundamental physiologic processes [12], but a higher concentration of iron could induce cellular apoptosis [19]. Therefore, the cell motility rate in iron-based implant was higher.

\subsection{In Vivo Examination}

3.3.1. Mineral Concentration. Figure 3 shows the mineral concentration including calcium, phosphorus, and iron of iron-based implant in tibial shaft fracture during 9 months' observation time after implantation in sheep. Insignificant difference in calcium concentration (Figure 3(a)) and significant differences in phosphorus concentration (Figure 3(b)) in each group were seen along with observation time. Ironbased implant shows the calcium concentration slightly 


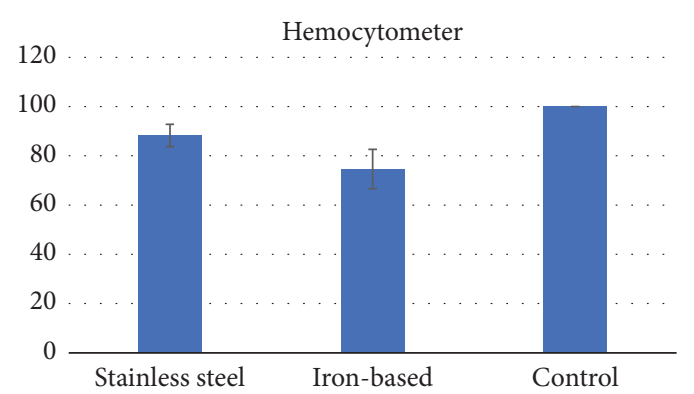

(a)

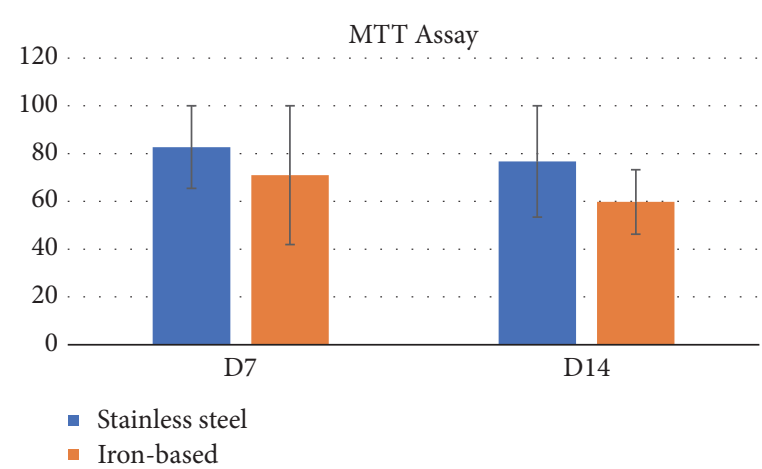

(b)

FIGURE 2: Calf pulmonary artery endothelial cell viability of iron-based and stainless steel implant using (a) haemocytometer and (b) MTT Assay.

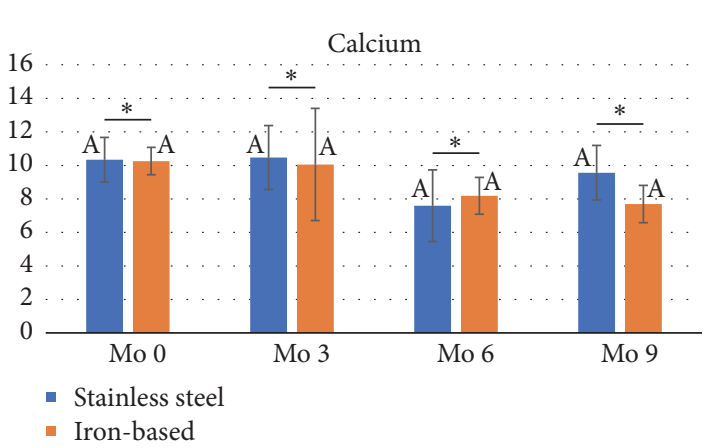

(a)

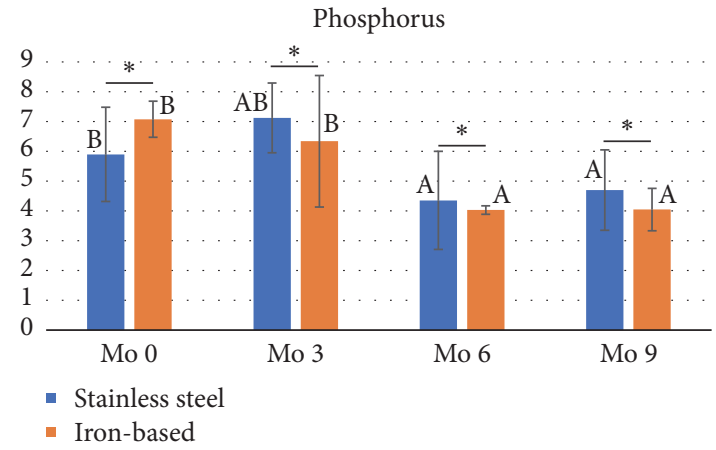

(b)

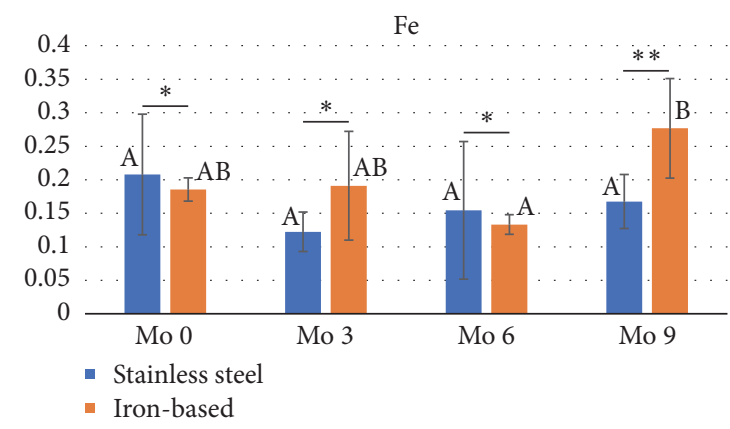

(c)

FIGURE 3: Mineral concentration of iron-based implant in tibial shaft fracture during 9 months' observation time after implantation in sheep (a) calcium, (b) phosphorus, and (c) iron concentration. The same superscript letters (A, B) in same group showed no significant differences during observation time, $*$ insignificant differences and $* *$ significant difference between both groups in same observation times $(\mathrm{P}>0.05)$. Mo: month.

decline along the observation time. Fracture healing is characterized by several overlapping stages which result in regenerated bone, namely, an inflammation phase, soft callus phase, and hard callus phase [20]. Calcium and phosphorus are essential bone-forming minerals. These minerals are required for the appropriate osteoblast adhesion, proliferation, and matrix deposition [21,22]. Calcium is a potential mediator for accelerating the calcification of bone formed [23]; phosphorus plays a critical role in physiological bone matrix mineralization.
Normal iron serum in sheep is varied according to the different authors. The iron serum in this study was still in the normal range [24]. During observation time, the highest iron concentration is at month 9 (Figure 3(c)), indicating ironion release in line with observation time [25]. Excess iron facilitates osteoclast differentiation, which is multinucleated giant cells, and bone resorption [26,27]. Previous studies also have demonstrated that higher iron level will also increase the intracellular ferroportin 1 (FPN-1) in osteoblast and other cells to maintain the iron homeostasis [28]. Iron which is not 
TABLE 1: Erythrocyte profile and thrombocyte of iron-based implant in tibia shaft fracture in month 0 until month 9 after implantation in sheep.

\begin{tabular}{|c|c|c|c|c|c|}
\hline Mo(s) & Groups & Haemoglobin $(\mathrm{g} / \mathrm{dL})$ & $\begin{array}{l}\text { Erythrocyte } \\
\left(10^{6} / \mu \mathrm{L}\right)\end{array}$ & $\begin{array}{c}\text { Haematocrit } \\
(\%)\end{array}$ & $\begin{array}{c}\text { Thrombocyte } \\
\left(10^{3} / \mu \mathrm{L}\right)\end{array}$ \\
\hline \multirow[t]{2}{*}{0} & SS & $9.75 \pm 0.54^{\mathrm{a}}$ & $3.43 \pm 0.10^{\mathrm{a}}$ & $30 \pm 1.41^{\mathrm{a}}$ & $201.5 \pm 91.27^{\mathrm{a}}$ \\
\hline & $\mathrm{Fe}$ & $10.42 \pm 1.02^{\mathrm{a}}$ & $3.48 \pm 0.21^{\mathrm{a}}$ & $30.75 \pm 2.63^{a}$ & $124.25 \pm 30.42^{\mathrm{a}}$ \\
\hline \multirow[t]{2}{*}{1} & SS & $10.95 \pm 2.72^{\mathrm{a}}$ & $3.73 \pm 0.88^{a}$ & $33.25 \pm 7.93^{\mathrm{a}}$ & $208.75 \pm 57.89^{a}$ \\
\hline & $\mathrm{Fe}$ & $9.53 \pm 1.3^{\mathrm{a}}$ & $3.33 \pm 0.46^{\mathrm{a}}$ & $29 \pm 4.55^{\mathrm{a}}$ & $132.5 \pm 35.27^{\mathrm{a}}$ \\
\hline \multirow[t]{2}{*}{2} & SS & $11 \pm 2.27^{\mathrm{a}}$ & $3.63 \pm 0.77^{\mathrm{a}}$ & $33.25 \pm 6.9^{\mathrm{a}}$ & $151.75 \pm 80.85^{\mathrm{a}}$ \\
\hline & $\mathrm{Fe}$ & $11.77 \pm 3.04^{\mathrm{a}}$ & $3.98 \pm 0.99^{\mathrm{a}}$ & $36 \pm 8.91^{\mathrm{a}}$ & $144.25 \pm 56.51^{\mathrm{a}}$ \\
\hline \multirow[t]{2}{*}{3} & SS & $10.47 \pm 1.05^{\mathrm{a}}$ & $3.5 \pm 0.37^{\mathrm{a}}$ & $31.75 \pm 2.99^{\mathrm{a}}$ & $134.75 \pm 43.81^{\mathrm{a}}$ \\
\hline & $\mathrm{Fe}$ & $11 \pm 0.67^{\mathrm{a}}$ & $3.57 \pm 0.29^{\mathrm{a}}$ & $33 \pm 2^{a}$ & $113.5 \pm 9,11^{\mathrm{a}}$ \\
\hline \multirow[t]{2}{*}{4} & SS & $9.53 \pm 0.43^{\mathrm{a}, \mathrm{x}}$ & $3.13 \pm 0.13^{\mathrm{a}, \mathrm{x}}$ & $28.5 \pm 1.73^{\mathrm{a}}$ & $130.5 \pm 61.2^{\mathrm{a}}$ \\
\hline & $\mathrm{Fe}$ & $10.33 \pm 0.39^{\mathrm{a}, \mathrm{x}}$ & $3.43 \pm 0.13^{\mathrm{a}, \mathrm{x}}$ & $31 \pm 1.41^{\mathrm{a}}$ & $107.75 \pm 6.9^{\mathrm{a}}$ \\
\hline \multirow[t]{2}{*}{5} & SS & $10.55 \pm 1.03^{\mathrm{a}}$ & $3.53 \pm 0.32^{\mathrm{a}}$ & $32.25 \pm 2.63^{\mathrm{a}}$ & $112.75 \pm 14.75^{\mathrm{a}}$ \\
\hline & $\mathrm{Fe}$ & $10.76 \pm 1.4^{\mathrm{a}}$ & $3.58 \pm 0.46^{\mathrm{a}}$ & $32.25 \pm 4.11^{\mathrm{a}}$ & $148.25 \pm 42.28^{a}$ \\
\hline \multirow[t]{2}{*}{6} & SS & $10.98 \pm 1.19^{\mathrm{a}}$ & $3.65 \pm 0.37^{\mathrm{a}}$ & $33 \pm 3.37^{\mathrm{a}}$ & $119.5 \pm 15.44^{\mathrm{a}}$ \\
\hline & $\mathrm{Fe}$ & $9.98 \pm 0.19^{\mathrm{a}}$ & $3.35 \pm 0.1^{\mathrm{a}}$ & $29.75 \pm 0.5^{\mathrm{a}}$ & $159.5 \pm 42.66^{\mathrm{a}}$ \\
\hline \multirow[t]{2}{*}{7} & SS & $10.25 \pm 0.87^{\mathrm{a}}$ & $3.4 \pm 0.29^{\mathrm{a}}$ & $31.25 \pm 3.3^{\mathrm{a}}$ & $193 \pm 122.52^{\mathrm{a}}$ \\
\hline & $\mathrm{Fe}$ & $11.2 \pm 1.22^{\mathrm{a}}$ & $3.7 \pm 0.44^{\mathrm{a}}$ & $33.33 \pm 3.79^{\mathrm{a}}$ & $134.33 \pm 32.56^{\mathrm{a}}$ \\
\hline \multirow[t]{2}{*}{8} & SS & $10.65 \pm 0.83^{\mathrm{a}}$ & $3.53 \pm 0.25^{\mathrm{a}}$ & $33 \pm 2.45^{\mathrm{a}}$ & $168.5 \pm 118.49^{a}$ \\
\hline & $\mathrm{Fe}$ & $11 \pm 0.4^{\mathrm{a}}$ & $3.67 \pm 0.15^{\mathrm{a}}$ & $33 \pm 1^{\mathrm{a}}$ & $145.67 \pm 32.35^{\mathrm{a}}$ \\
\hline \multirow[t]{2}{*}{9} & SS & $10.58 \pm 0.71^{\mathrm{a}}$ & $3.5 \pm 0.26^{\mathrm{a}}$ & $31.75 \pm 2.22^{\mathrm{a}}$ & $115.75 \pm 6.99^{\mathrm{a}}$ \\
\hline & $\mathrm{Fe}$ & $9.67 \pm 1.07^{\mathrm{a}}$ & $3.33 \pm 0.31^{\mathrm{a}}$ & $29.66 \pm 3.06^{\mathrm{a}}$ & $141.67 \pm 44.96^{\mathrm{a}}$ \\
\hline
\end{tabular}

Description: data is presented in the average \pm standard deviation. The same superscript letters $(\mathrm{a}, \mathrm{b}, \mathrm{c})$ in different rows but in the same group showed no significant differences $(\mathrm{P}>0.05)$. The same superscript letters $(\mathrm{x})$ in different rows and the different group showed no significant differences $(\mathrm{P}>0.05)$. Mo: month, SS: stainless steel group, Fe: iron-based group.

utilized is stored as ferritin in some cell types. Ferritin stores iron in a nontoxic form and contributes to intracellular iron bioavailability [29].

3.3.2. Erythrocyte Profiles. Erythrocyte profile and thrombocyte of iron-based implant compared to stainless steel implant could be seen in Table 1. Immediately after bone fracture, a hematoma is formed from the bleeding at the fracture site. The hematoma fills the fracture gap in the initial step of bone healing. In the iron-based group, an insignificant decrease of erythrocyte is observed at month 1 , in contrast to the stainless steel group. Iron-based implant surface is rougher than the stainless steel surface (Figure 1). Thus, it induced higher hemolysis than stainless steel implant. Bone implant surfaces are meant to positively modulate the interfacial response between the implant and host tissue [30].

At month 4 the number of erythrocytes in the stainless steel group was the lowest from the record gathered and it was significantly different with the iron-based (Table 2). Osteointegration of sheep could be achieved in the $4^{\text {th }}$ month of the healing period [31]. In fracture cases due to hemolysis, lack of erythrocyte will lead to lack of hemoglobin. Bone marrow erythroblasts require a large amount of iron for hemoglobin synthesis [32]. The average lifespan of circulating erythrocytes is approximately 120 days. Within macrophages, hemoglobin derived from phagocytes erythrocytes and free iron is released for circulation [33].

The patterns of erythrocyte, hematocrit, and hemoglobin are alike. An insignificant increase of the patterns indicates light erythropoiesis increases in response to blood loss and inflammation. The increase is caused by the implantation procedures in the early postimplantation, implant-bone tissue interaction, and implant-bone marrow interaction $[34,35]$.

Thrombocytes, also known as platelets, are the smallest cells of the blood which play a key role in blood clotting and stimulating bone tissue regeneration [36] induced by platelet-derived growth factor [37]. Insignificant changes are also seen in the average number of thrombocyte (Table 1). Although insignificant, the average number of thrombocytes at month 7 is higher than that of month 6 in stainless steel group. The differences are also seen at month 0 and 1. During both observation times, the average number of thrombocytes in stainless steel group is higher than the ironbased group. Thrombocyte increase might be associated with inflammatory, blood loss, or iron deficiency [38].

3.3.3. Leukocyte Count and Differential Leukocytes. Leucocytes, also known as white blood cells, defend the body against disease-causing organisms, toxins, and irritants. Figure 4 shows the number of leucocytes responses in sheep 
TABLE 2: Differential leucocytes of iron-based implant in tibia shaft fracture in month 0 until 9 after implantation in sheep.

\begin{tabular}{|c|c|c|c|c|c|c|c|}
\hline Mo & Group & Eosinophil (\%) & Neutrophil band (\%) & Neutrophil Segmented (\%) & Lymphocyte (\%) & Monocyte (\%) & Basophil (\%) \\
\hline \multirow[t]{2}{*}{0} & SS & $0.25 \pm 0.5^{\mathrm{a}}$ & $2 \pm 1.41^{\mathrm{a}}$ & $70.25 \pm 8.18^{\mathrm{a}}$ & $22.5 \pm 6.76^{\mathrm{a}}$ & $4 \pm 1.82^{\mathrm{a}}$ & $0 \pm 0^{\mathrm{a}}$ \\
\hline & $\mathrm{Fe}$ & $0.75 \pm 0.96^{\mathrm{a}}$ & $1.25 \pm 1.5^{\mathrm{a}}$ & $73 \pm 10.13^{\mathrm{a}}$ & $22.25 \pm 10.05^{\mathrm{a}}$ & $2.75 \pm 0.96^{\mathrm{a}}$ & $0 \pm 0^{\mathrm{a}}$ \\
\hline \multirow[t]{2}{*}{1} & SS & $1 \pm 0.82^{\mathrm{a}}$ & $2.25 \pm 1.71^{\mathrm{a}}$ & $66 \pm 13.37^{\mathrm{a}}$ & $28 \pm 11.23^{\mathrm{a}}$ & $2.75 \pm 1.5^{\mathrm{a}}$ & $0 \pm 0^{\mathrm{a}}$ \\
\hline & $\mathrm{Fe}$ & $1 \pm 0.82^{\mathrm{a}}$ & $1 \pm 1.15^{\mathrm{a}}$ & $62.5 \pm 10.21^{\mathrm{a}}$ & $32.25 \pm 8.96^{\mathrm{a}}$ & $3.5 \pm 0.58^{\mathrm{a}}$ & $0 \pm 0^{\mathrm{a}}$ \\
\hline \multirow[t]{2}{*}{2} & SS & $0.25 \pm 0.5^{\mathrm{a}}$ & $1.25 \pm 1.26^{\mathrm{a}}$ & $73.25 \pm 3.95^{\mathrm{a}}$ & $21.75 \pm 4.35^{\mathrm{a}}$ & $3.5 \pm 1.91^{\mathrm{a}}$ & $0 \pm 0^{\mathrm{a}}$ \\
\hline & $\mathrm{Fe}$ & $0.5 \pm 1^{\mathrm{a}}$ & $1 \pm 1.15^{\mathrm{a}}$ & $75.75 \pm 3.30^{\mathrm{a}}$ & $20 \pm 2.94^{\mathrm{a}}$ & $2.75 \pm 2.22^{\mathrm{a}}$ & $0 \pm 0^{\mathrm{a}}$ \\
\hline \multirow[t]{2}{*}{3} & SS & $0.75 \pm 0.96^{\mathrm{a}}$ & $1.75 \pm 1.26^{\mathrm{a}}$ & $71 \pm 2^{\mathrm{a}}$ & $24.5 \pm 3.70^{\mathrm{a}}$ & $2.5 \pm 1.29^{\mathrm{a}}$ & $0 \pm 0^{\mathrm{a}}$ \\
\hline & $\mathrm{Fe}$ & $0.5 \pm 1^{\mathrm{a}}$ & $1 \pm 1.15^{\mathrm{a}}$ & $62.5 \pm 9.95^{\mathrm{a}}$ & $32.75 \pm 9.11^{\mathrm{a}}$ & $3.25 \pm 2.5^{\mathrm{a}}$ & $0 \pm 0^{\mathrm{a}}$ \\
\hline \multirow[t]{2}{*}{4} & SS & $0 \pm 0^{\mathrm{a}}$ & $0.75 \pm 1.5^{\mathrm{a}}$ & $71.25 \pm 5.68^{\mathrm{a}}$ & $25.5 \pm 4.20^{\mathrm{a}}$ & $2.5 \pm 1^{\mathrm{a}}$ & $0 \pm 0^{a}$ \\
\hline & $\mathrm{Fe}$ & $0.5 \pm 0.58^{\mathrm{a}}$ & $1.25 \pm 1.5^{\mathrm{a}}$ & $67.75 \pm 5.85^{\mathrm{a}}$ & $28 \pm 4.97^{\mathrm{a}}$ & $2.5 \pm 0.58^{\mathrm{a}}$ & $0 \pm 0^{\mathrm{a}}$ \\
\hline \multirow[t]{2}{*}{5} & SS & $0.5 \pm 1^{\mathrm{a}}$ & $0.75 \pm 0.96^{\mathrm{a}}$ & $73.25 \pm 4.64^{\mathrm{a}}$ & $18.5 \pm 11.39^{\mathrm{a}}$ & $2 \pm 2.83^{\mathrm{a}}$ & $0 \pm 0^{\mathrm{a}}$ \\
\hline & $\mathrm{Fe}$ & $0.25 \pm 0.5^{\mathrm{a}}$ & $1.75 \pm 1.26^{\mathrm{a}}$ & $69 \pm 3.56^{\mathrm{a}}$ & $26 \pm 2.94^{\mathrm{a}}$ & $3 \pm 1.15^{\mathrm{a}}$ & $0 \pm 0^{\mathrm{a}}$ \\
\hline \multirow[t]{2}{*}{6} & SS & $0.75 \pm 0.96^{\mathrm{a}}$ & $1.25 \pm 0.96^{\mathrm{a}}$ & $63.75 \pm 7.41^{\mathrm{a}}$ & $30 \pm 4.97^{\mathrm{a}}$ & $3 \pm 0.82^{\mathrm{a}}$ & $0 \pm 0^{\mathrm{a}}$ \\
\hline & $\mathrm{Fe}$ & $0.25 \pm 0.5^{\mathrm{a}}$ & $1 \pm 1.15^{\mathrm{a}}$ & $64.25 \pm 6.18^{\mathrm{a}}$ & $34.25 \pm 2.36^{\mathrm{a}}$ & $2.75 \pm 1.71^{\mathrm{a}}$ & $0 \pm 0^{\mathrm{a}}$ \\
\hline \multirow[t]{2}{*}{7} & SS & $0.75 \pm 0.96^{\mathrm{a}}$ & $1.75 \pm 1.26^{\mathrm{a}}$ & $67.25 \pm 12.71^{\mathrm{a}}$ & $27.75 \pm 10.91^{\mathrm{a}}$ & $2.5 \pm 1.29^{\mathrm{a}}$ & $0 \pm 0^{\mathrm{a}}$ \\
\hline & $\mathrm{Fe}$ & $1 \pm 1^{\mathrm{a}}$ & $1.33 \pm 1.15^{\mathrm{a}}$ & $67.33 \pm 12,34^{\mathrm{a}}$ & $27 \pm 12.12^{\mathrm{a}}$ & $3.33 \pm 1.53^{\mathrm{a}}$ & $0 \pm 0^{\mathrm{a}}$ \\
\hline \multirow[t]{2}{*}{8} & SS & $1.5 \pm 0.58^{\mathrm{a}}$ & $2.25 \pm 0.5^{\mathrm{a}}$ & $62 \pm 5.48^{\mathrm{a}, \mathrm{x}}$ & $32.5 \pm 5.97^{\mathrm{a}, \mathrm{x}}$ & $1.75 \pm 0.5^{\mathrm{a}}$ & $0 \pm 0^{\mathrm{a}}$ \\
\hline & $\mathrm{Fe}$ & $0.67 \pm 0.58^{\mathrm{a}}$ & $2 \pm 0^{\mathrm{a}}$ & $71 \pm 1.73^{\mathrm{a}, \mathrm{x}}$ & $23 \pm 1^{\mathrm{a}, \mathrm{x}}$ & $3.33 \pm 1.15^{\mathrm{a}}$ & $0 \pm 0^{\mathrm{a}}$ \\
\hline \multirow[t]{2}{*}{9} & SS & $0.25 \pm 0.5^{\mathrm{a}}$ & $1 \pm 1.15^{\mathrm{a}}$ & $67.75 \pm 5.44^{\mathrm{a}}$ & $28.5 \pm 3.87^{\mathrm{a}}$ & $2.5 \pm 1.73^{\mathrm{a}}$ & $0 \pm 0^{\mathrm{a}}$ \\
\hline & $\mathrm{Fe}$ & $0.67 \pm 1.15^{\mathrm{a}}$ & $2.33 \pm 0.58^{\mathrm{a}}$ & $73 \pm 2.65^{\mathrm{a}}$ & $23.67 \pm 1.53^{a}$ & $2.33 \pm 0.58^{\mathrm{a}}$ & $0 \pm 0^{\mathrm{a}}$ \\
\hline
\end{tabular}

Description: data is presented in the average \pm standard deviation. The same superscript letters $(\mathrm{a}, \mathrm{b}, \mathrm{c})$ in different rows but in the same group showed no significant differences $(\mathrm{P}>0.05)$. The same superscript letters $(\mathrm{x})$ in different rows and the different group showed no significant differences $(\mathrm{P}>0.05)$. Mo: month.

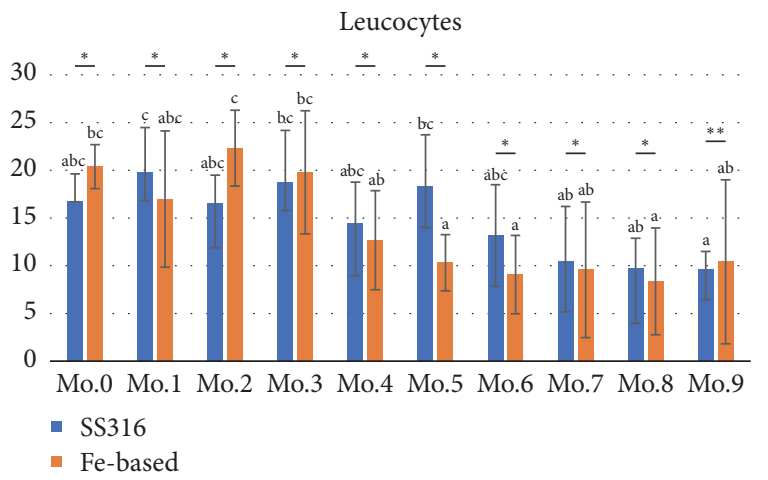

FIgURE 4: The number of leucocytes in tibial shaft fracture during 9 months of observation time after implantation in sheep. * insignificant differences and $* *$ significant difference between both groups in same observation times $(\mathrm{P}>0.05)$. Mo: month.

during 9 months of observation time after iron-based and stainless steel implantation. An inflammatory response could be observed using white blood cell analysis expressed in Table 2. White blood cell examination was performed to analyze the metal hypersensitivity reaction [39] and inflammatory response $[40,41]$ that could be affected by bone fracture healing [42]. Leucocytes of iron-based implant group show significant changes (Figure 4) during observation time compared to stainless steel implant. Table 2 also shows, almost in all observation times, that the level of leukocyte of iron-based implant is higher than stainless steel implant, especially at month 9 .
An inflammatory response of iron-based implant to the body could be observed using leucocyte differentiation analysis which is expressed in Table 2. Eosinophils are a minor circulating granulocyte. They are normally present in low number. Eosinophil-rich inflammation has long been associated with host defense against parasites, promoting allergic reactions [43]. An iron overload could induce eosinophil hyperactivity in mouse and human $[44,45]$. In this study, eosinophils data insignificantly changed (Table 2), indicating that the implants have a minimum allergic reaction.

Neutrophils, the first cells recruited to sites of inflammations [46], play a pathos-mechanistic role in compromised bone healing and activated in posttraumatic systemic inflammation [47]. During bone fracture healing, neutrophil synthesizes fibronectin in the gap of fracture [48]. The highest level of neutrophil is seen at month 9 in iron-based implant group (Table 2) along with the highest iron concentration. There is no significant difference in this study, implying minimal inflammation response along the bone healing process.

Bone fracture, as well as the interruption of blood supply and platelet aggregation, induces the release of plateletderived proinflammatory cytokines, interleukin-6 (IL-6), IL-1, IL-2, and tumor necrosis factor-alpha (TNF- $\alpha$ ) [49]. These cytokines stimulate the homing of lymphocytes and monocytes/macrophages [50]. In this study, almost in all observation times, the average percentage of lymphocytes of the iron-based group was higher than stainless steel group. Lymphocytes are present at the early inflammatory phase during the initiation of bone repair and in the remodeling 
TABLE 3: Blood chemistry results of iron-based implant in tibia shaft fracture in month 0 until 9 after implantation in sheep.

\begin{tabular}{|c|c|c|c|c|c|}
\hline $\mathrm{Mo}(\mathrm{s})$ & Groups & $\begin{array}{r}\text { SGPT } \\
(\mu / \mathrm{L}) \\
\end{array}$ & $\begin{array}{r}\text { SGOT } \\
(\mu / \mathrm{L})\end{array}$ & $\begin{array}{c}\text { BUN } \\
(\mathrm{mg} / \mathrm{dL})\end{array}$ & $\begin{array}{c}\text { Creatinine } \\
(\mathrm{mg} / \mathrm{dL})\end{array}$ \\
\hline \multirow[t]{2}{*}{0} & SS & $30.25 \pm 14.93^{\mathrm{a}}$ & $25 \pm 13.44^{\mathrm{a}}$ & $39.75 \pm 2.36^{\mathrm{d}, \mathrm{x}}$ & $1.1 \pm 0.48^{c}$ \\
\hline & $\mathrm{Fe}$ & $23.5 \pm 12.50^{\mathrm{a}}$ & $31 \pm 7.87^{\mathrm{a}}$ & $25 \pm 10.39^{\mathrm{a}, \mathrm{x}}$ & $0.7 \pm 0.22^{\mathrm{a}}$ \\
\hline \multirow[t]{2}{*}{1} & SS & $27.25 \pm 10.78^{a}$ & $27.25 \pm 10.18^{\mathrm{a}}$ & $28.25 \pm 5.12^{\mathrm{abc}}$ & $0.95 \pm 0.26^{\mathrm{abc}}$ \\
\hline & $\mathrm{Fe}$ & $35 \pm 6.21^{\mathrm{a}}$ & $32.75 \pm 3.77^{\mathrm{a}}$ & $2925 \pm 6.02^{\mathrm{a}}$ & $0.65 \pm 0.19^{a}$ \\
\hline \multirow[t]{2}{*}{2} & SS & $39.5 \pm 5.20^{\mathrm{a}}$ & $28 \pm 4.24^{\mathrm{a}}$ & $36 \pm 3.65^{\mathrm{cd}}$ & $1.05 \pm 0.3^{\mathrm{bc}, \mathrm{x}}$ \\
\hline & $\mathrm{Fe}$ & $33 \pm 8.49^{\mathrm{a}}$ & $29.75 \pm 10.97^{a}$ & $30 \pm 7.26^{\mathrm{a}}$ & $0.45 \pm 0.21^{\mathrm{a}, \mathrm{x}}$ \\
\hline \multirow[t]{2}{*}{3} & SS & $26.25 \pm 8.5^{\mathrm{a}}$ & $30 \pm 12.94^{\mathrm{a}}$ & $23.25 \pm 5.67^{\mathrm{a}}$ & $0.53 \pm 0.15^{\mathrm{a}}$ \\
\hline & $\mathrm{Fe}$ & $29 \pm 9.27^{\mathrm{a}}$ & $36.75 \pm 2.87^{\mathrm{a}}$ & $28.75 \pm 8.18^{\mathrm{a}}$ & $0.75 \pm 0.44^{\mathrm{a}}$ \\
\hline \multirow[t]{2}{*}{4} & SS & $31.75 \pm 12.26^{\mathrm{a}}$ & $25 \pm 8.49^{a}$ & $33,75 \pm 4.35^{\mathrm{bcd}}$ & $1.18 \pm 0.3^{\mathrm{d}, \mathrm{x}}$ \\
\hline & $\mathrm{Fe}$ & $32 \pm 6.53^{\mathrm{a}}$ & $27.75 \pm 4.86^{a}$ & $23.5 \pm 8.27^{\mathrm{a}}$ & $0.6 \pm 0.22^{\mathrm{a}, \mathrm{x}}$ \\
\hline \multirow[t]{2}{*}{5} & SS & $36 \pm 6.06^{\mathrm{a}}$ & $28.75 \pm 11.41^{\mathrm{a}}$ & $28.5 \pm 2.08^{a b c}$ & $0.6 \pm 0.18^{\mathrm{ab}}$ \\
\hline & $\mathrm{Fe}$ & $26.5 \pm 12.29^{\mathrm{a}}$ & $36.25 \pm 10.63^{\mathrm{a}}$ & $27.75 \pm 6.55^{\mathrm{a}}$ & $0.6 \pm 0.18^{\mathrm{a}}$ \\
\hline \multirow[t]{2}{*}{6} & SS & $30 \pm 16.35^{\mathrm{a}}$ & $30.5 \pm 7.14^{\mathrm{a}}$ & $21.75 \pm 9.46^{\mathrm{a}}$ & $0.6 \pm 0.24^{\mathrm{ab}}$ \\
\hline & $\mathrm{Fe}$ & $33.75 \pm 7.27^{\mathrm{a}}$ & $29.25 \pm 9.98^{a}$ & $24.25 \pm 4.79^{\mathrm{a}}$ & $0.68 \pm 0.22^{\mathrm{a}}$ \\
\hline \multirow[t]{2}{*}{7} & SS & $29 \pm 3.46^{\mathrm{a}}$ & $32.25 \pm 3.20^{\mathrm{a}}$ & $25 \pm 6.78^{a b}$ & $0.75 \pm 0.33^{a b c}$ \\
\hline & $\mathrm{Fe}$ & $33.67 \pm 8.74^{\mathrm{a}}$ & $29 \pm 11.53^{\mathrm{a}}$ & $22 \pm 8.19^{a}$ & $0.57 \pm 0.15^{\mathrm{a}}$ \\
\hline \multirow[t]{2}{*}{8} & SS & $25.25 \pm 5.32^{\mathrm{a}}$ & $31.25 \pm 9.11^{\mathrm{a}}$ & $23 \pm 8.04^{\mathrm{a}, \mathrm{x}}$ & $0.88 \pm 0.40^{b c}$ \\
\hline & $\mathrm{Fe}$ & $31.67 \pm 14.57^{\mathrm{a}}$ & $36.67 \pm 11.15^{\mathrm{a}}$ & $36 \pm 2^{\mathrm{a}, \mathrm{x}}$ & $0.7 \pm 0.2^{\mathrm{a}}$ \\
\hline \multirow[t]{2}{*}{9} & SS & $24.75 \pm 6.75^{\mathrm{a}}$ & $30.5 \pm 11.79^{a}$ & $29 \pm 3.16^{a b c}$ & $0.6 \pm 0.16^{\mathrm{ab}}$ \\
\hline & $\mathrm{Fe}$ & $34 \pm 10.58^{a}$ & $27.67 \pm 11.72^{a}$ & $32 \pm 9.16^{\mathrm{a}}$ & $0.87 \pm 0.31^{\mathrm{a}}$ \\
\hline
\end{tabular}

Description: the data is presented in the average \pm standard deviation. The same superscript letters $(\mathrm{a}, \mathrm{b}, \mathrm{c})$ in different rows but in the same group showed no significant differences $(\mathrm{P}>0.05)$. The same superscript letters $(\mathrm{x})$ in different rows and the different group showed no significant differences $(\mathrm{P}>0.05)$. Mo: month, SS: stainless steel, Fe: iron-based implant, SGPT: serum glutamic pyruvic transaminase, SGOT: serum glutamic oxaloacetic transaminase, BUN: blood urea nitrogen.

phase. The lymphocyte is involved in hard callus remodeling to support osteogenesis [51,52] with high production of proinflammatory cytokine IL-17 to stimulate the proliferation and osteoblastic differentiation of mesenchymal progenitor cells [53]. Although insignificant, iron-based implant stimulates more severe bone injury than stainless steel implant. This could be caused by the surface of the implant, inducing more soft tissue defect and the concentration of iron that induced the higher inflammatory effect.

Monocyte can differentiate several subtypes of macrophage depending on environmental circumstances. Fractured bone releases the monocyte chemoattractant-1 (MCP-1) [47]. Macrophages play a central role in the organism as they recycle iron after phagocytosis of senescent erythrocytes and also the central contributors to reparative inflammation, coordinating both the injury response and tissue regeneration [53]. Interestingly, the average percentages of lymphocyte and macrophage at months 6 and 7 of the stainless steel group are in contrast to the number of hematocrits. Activated hematocrit attenuates inflammatory response of lymphocyte and macrophage to limit inflammatory processes [54].

3.3.4. Blood Biochemistry of Liver and Kidney. Blood chemistry examination including serum glutamic pyruvic transaminase, serum glutamic oxaloacetic transaminase, blood urea nitrogen, and creatinine could be seen in Table 3. The liver is the primary organ for supporting rapid erythrocyte removal, iron recycling [55], and iron storage [32]. Excess iron would reduce plasma calcium and phosphorus level along with decrease of liver and kidney function [56]. In this study, in line with having no significant differences in the concentration of calcium and phosphorus (Table 3), no significant difference in serum glutamic pyruvic transaminase and serum glutamic oxaloacetic transaminase results indicates the liver function of sheep in both groups is still acceptable.

Majority of metabolic products are excreted via the kidney. Most of the iron in circulation is bound to transferrin, which in the kidney can be taken up via transferrin receptor 1 [57] and reabsorbed by endocytosis in the proximal and distal tubules [58]. Insignificant differences in the ironbased group indicate this implant is still tolerable during 9month observation time (Table 3 ). Although the degree of nephrotoxicity is influenced by iron concentration and the duration of iron-nephrocyte interaction [59], the iron level has no significant effects in early chronic kidney disease [60].

Interestingly, there are contradictory results regarding the creatinine index in this study. Creatinine has no useful function and is eliminated by renal glomerular filtration and to a small extent by renal tubular secretion [46]. Creatinine is correlated with skeletal muscle mass. Significant differences 
are seen during the early three months period in stainless steel group. As mentioned above, hemolysis and lack of erythrocyte will lead to lack of hemoglobin in fracture cases. These conditions will induce kidney to synthesize erythropoietin increase [61], a glycoprotein hormone that regulates erythrocyte production [46], leading to creatinine decrease [62] during early observation time. At month 4, the creatinine level slightly increases probably due to the increased bone density [63]. In human, low creatinine also was positively associated with bone density. The insignificant decrease [64] of creatinine during the last observation time indicates the initial bone density is still not achieved. Generally, this study discussed the biocompatibility effects of the iron-based compared to the stainless steel bone implant in the systemic body of the sheep using blood count, blood mineral concentration, and blood biochemistry examination. To understand more about the local effects of those materials to the bone tissue, histopathology examination should be conducted.

\section{Conclusions}

In this study, the iron-based implant had maintained high cell viability and had induced minimum erythrocyte profile, leucocyte number, leucocyte differential count, and also blood chemistry responses. Thus, it can be concluded that iron-based implant has potential as an intramedullary nail in tibia shaft fracture of sheep.

\section{Data Availability}

The data used to support the findings of this study are included within the article.

\section{Conflicts of Interest}

The authors declared no conflicts of interest.

\section{Acknowledgments}

The research was funded by the Indonesia Ministry of Research, Technology and Higher Education in international research collaboration and scientific publication.

\section{References}

[1] M. Cruz-Sánchez, R. Torres-Claramunt, A. Alier-Fabregó, and S. Martínez-Díaz, "Salvage for nail breakage in femoral intramedullary nailing," Injury, vol. 46, no. 4, pp. 729-733, 2015.

[2] L. Wilson, "Repair of sacral fractures using pins and polymethylmethacrylate (six cases)," Australian Veterinary Journal, vol. 93, no. 9, pp. 311-318, 2015.

[3] N. L. Duplantier, R. J. Mitchell, S. Zambrano et al., "A biomechanical comparison of fifth metatarsal jones fracture fixation methods," The American Journal of Sports Medicine, vol. 46, no. 5, pp. 1220-1227, 2018.

[4] A. Sultan, M. R. Bhat, O. Khursheed et al., "Evaluation of complications from stainless-steel flexible intramedullary nailing in children's femoral shaft fractures and recommendations for continued use," Ortopedia Traumatologia Rehabilitacja, vol. 19, no. 3, pp. 263-271, 2017.

[5] V. Sansone, D. Pagani, and M. Melato, "The effects on bone cells of metal ions released from orthopaedic implants. A review," Clinical Cases in Mineral and Bone Metabolism, vol. 10, no. 1, pp. 34-40, 2013.

[6] M. Seyhan, O. Guler, M. Mahirogullari, F. Donmez, A. Gereli, and S. Mutlu, "Complications during removal of stainless steel versus titanium nails used for intramedullary nailing of diaphyseal fractures of the tibia," Annals of Medicine and Surgery, vol. 26, pp. 38-42, 2018.

[7] Y. F. Zheng, X. N. Gu, and F. Witte, "Biodegradable metals," Materials Science and Engineering: R: Reports, vol. 77, pp. 1-34, 2014.

[8] M. F. Ulum, A. Arafat, D. Noviana et al., "In vitro and in vivo degradation evaluation of novel iron-bioceramic composites for bone implant applications," Materials Science and Engineering C: Materials for Biological Applications, vol. 36, no. 1, pp. 336344, 2014.

[9] T. Ganz, "Iron and infection," International Journal of Hematology, vol. 107, no. 1, pp. 7-15, 2018.

[10] M. D. Cappellini, J. Comin-Colet, A. de Francisco et al., "Iron deficiency across chronic inflammatory conditions: International expert opinion on definition, diagnosis, and management," American Journal of Hematology, vol. 92, no. 10, pp. 2068-2078, 2017.

[11] A. H. M. Yusop, N. M. Daud, H. Nur, M. R. A. Kadir, and H. Hermawan, "Controlling the degradation kinetics of porous iron by poly(lactic-co-glycolic acid) infiltration for use as temporary medical implants," Scientific Reports, vol. 5, Article ID 11194, 2015.

[12] C. Doguer, J. H. Ha, S. Gulec, C. D. Vulpe, G. J. Anderson, and J. F. Collins, "Intestinal hephaestin potentiates iron absorption in weanling, adult, and pregnant mice under physiological conditions," Blood Advances, vol. 1, no. 17, pp. 1335-1347, 2017.

[13] I. R. Dias, J. A. Camassa, J. A. Bordelo et al., "Preclinical and translational studies in small ruminants (sheep and goat) as models for osteoporosis research," Current Osteoporosis Reports, vol. 16, no. 2, pp. 182-197, 2018.

[14] C. P. Sousa, M. Lopez-Peña, F. M. Guzón et al., "Evaluation of bone turnover markers and serum minerals variations for predicting fracture healing versus non-union processes in adult sheep as a model for orthopedic research," Injury, vol. 48, no. 8, pp. 1768-1775, 2017.

[15] S. C. Sartoretto, M. J. Uzeda, F. B. Miguel, J. R. Nascimento, F. Ascoli, and M. D. Calasans-Maia, "Sheep as an experimental model for biomaterial implant evaluation," Acta Ortopédica Brasileira, vol. 24, no. 5, pp. 262-266, 2016.

[16] E. H. Mrosek, H.-W. Chung, J. S. Fitzsimmons, S. W. O’Driscoll, G. G. Reinholz, and J. C. Schagemann, "Porous tantalum biocomposites for osteochondral defect repair a follow-up study in a sheep model," Bone \& Joint Research, vol. 6, no. 5, pp. 403411, 2016.

[17] M. Silalahi, A. Dimyati, S. Harjanto, P. Untoro, and B. Suharno, "Microalloying of $\mathrm{Fe}-\mathrm{Cr}$ by using ultrasonic irradiation," International Journal of Technology, vol. 5, no. 2, pp. 169-182, 2014.

[18] M. Dadfar, M. H. Fathi, F. Karimzadeh, M. R. Dadfar, and A. Saatchi, "Effect of TIG welding on corrosion behavior of 316L stainless steel," Materials Letters, vol. 61, no. 11-12, pp. 23432346, 2007.

[19] V. Manickam, V. Dhakshinamoorthy, and E. Perumal, "Iron oxide nanoparticles induces cell cycle-dependent neuronal 
apoptosis in mice," Journal of Molecular Neuroscience, vol. 64, no. 3, pp. 352-362, 2018.

[20] K. Schmidt-Bleek, B. J. Kwee, D. J. Mooney, and G. N. Duda, "Boon and bane of inflammation in bone tissue regeneration and its link with angiogenesis," Tissue Engineering - Part B: Reviews, vol. 21, no. 4, pp. 354-364, 2015.

[21] C. S. Carlson and S. E. Weisbrode, Bones, Joints, Tendons, and Ligaments, Chapter 16 in Pathologic Basis of Veterinary Disease, Elsevier Inc, Missiouri, USA, 5th edition, 2012.

[22] M. K. Boushell, N. T. Khanarian, R. Z. LeGeros, and H. H. Lu, "Effect of ceramic calcium-phosphorus ratio on chondrocytemediated biosynthesis and mineralization," Journal of Biomedical Materials Research Part A, vol. 105, no. 10, pp. 2694-2702, 2017.

[23] K. A. Al Ruhaimi, "Effect of calcium sulphate on the rate of osteogenesis in distracted bone," International Journal of Oral and Maxillofacial Surgery, vol. 30, no. 3, pp. 228-233, 2001.

[24] M. E. Or, A. Kayar, A. R. Kiziler et al., "Determination of levels of some essential (iron, copper, zinc) and toxic (lead, cadmium) metals in the blood of sheep and in samples of water, plants and soil in Northwest Turkey," Veterinarski Arhiv, vol. 75, no. 4, pp. 359-368, 2005.

[25] J. Čapek, Š. Msallamová, E. Jablonská, J. Lipov, and D. Vojtěch, "A novel high-strength and highly corrosive biodegradable Fe-Pd alloy: Structural, mechanical and in vitro corrosion and cytotoxicity study," Materials Science and Engineering C: Materials for Biological Applications, vol. 79, pp. 550-562, 2017.

[26] E. Balogh, E. Tolnai, B. Nagy et al., "Iron overload inhibits osteogenic commitment and differentiation of mesenchymal stem cells via the induction of ferritin," Biochimica et Biophysica Acta (BBA) - Molecular Basis of Disease, vol. 1862, no. 9, pp. 1640-1649, 2016.

[27] W. Xie, S. Lorenz, S. Dolder, and W. Hofstetter, "Extracellular iron is a modulator of the differentiation of osteoclast lineage cells," Calcified Tissue International, vol. 98, no. 3, pp. 275-283, 2016.

[28] G.-Y. Zhao, D.-H. Di, B. Wang, P. Zhang, and Y.-J. Xu, "Iron regulates the expression of ferroportin 1 in the cultured $\mathrm{hFOB}$ 1.19 osteoblast cell line," Experimental and Therapeutic Medicine, vol. 8, no. 3, pp. 826-830, 2014.

[29] M. U. Muckenthaler, S. Rivella, M. W. Hentze, and B. Galy, "A red carpet for iron metabolism," Cell, vol. 168, no. 3, pp. 344-361, 2017.

[30] R. Bosco, J. Van Den Beucken, S. Leeuwenburgh, and J. Jansen, "Surface engineering for bone implants: A trend from passive to active surfaces," Coatings, vol. 2, no. 3, pp. 95-119, 2012.

[31] M. E. Yurttutan, R. Kestane, A. Keskin, and Ö. Dereci, "Biomechanical evaluation of oversized drilling on implant stability-an experimental study in sheep," Journal of the Pakistan Medical Association, vol. 66, no. 2, pp. 147-150, 2016.

[32] E. R. Anderson and Y. M. Shah, "Iron homeostasis in the liver," Comprehensive Physiology, vol. 3, no. 1, pp. 315-330, 2013.

[33] M. M. Fry, Anemia of Inflammatory, Neoplastic, Renal, and Endocrine Diseases. Chapter 37 in Schalm's Veterinary Hematology, A john Wiley \& Sons, Ltd, Hoboken, NJ, USA, 6th edition, 2002.

[34] S. Kaur, L. J. Raggatt, L. Batoon, D. A. Hume, J.-P. Levesque, and A. R. Pettit, "Role of bone marrow macrophages in controlling homeostasis and repair in bone and bone marrow niches," Seminars in Cell \& Developmental Biology, vol. 61, pp. 12-21, 2017.
[35] D. Kubies, L. Himmlová, T. Riedel et al., "The interaction of osteoblasts with bone-implant materials: 1 . The effect of physicochemical surface properties of implant materials," Physiological Research, vol. 60, no. 1, pp. 95-111, 2011.

[36] I. A. Rodriguez, E. A. Growney Kalaf, G. L. Bowlin, and S. A. Sell, "Platelet-rich plasma in bone regeneration: Engineering the delivery for improved clinical efficacy," BioMed Research International, vol. 2014, Article ID 392398, 15 pages, 2014.

[37] S. J. Kim, S. Y. Kim, C. H. Kwon, and Y. K. Kim, “Differential effect of FGF and PDGF on cell proliferation and migration in osteoblastic cells," Growth Factors, vol. 25, no. 2, pp. 77-86, 2007.

[38] N. Appleby and D. Angelov, "Clinical and laboratory assessment of a patient with thrombocytosis," British Journal of Hospital Medicine, vol. 78, no. 10, pp. 558-564, 2017.

[39] W. Z. W. Teo and C. Schalock, "Metal Hypersensitivity reactions to orthopedic implans," Dermatologic Therapy, vol. 7, no. 1, pp. 53-64, 2018.

[40] S. B. Goodman, Z. Yao, M. Keeney, and F. Yang, "The future of biologic coatings for orthopaedic implants," Biomaterials, vol. 34, no. 13, pp. 3174-3183, 2013.

[41] S. Landgraeber, M. Jäger, J. J. Jacobs, and N. J. Hallab, “The pathology of orthopedic implant failure is mediated by innate immune system cytokines," Mediators of Inflammation, vol. 2014, Article ID 185150, 9 pages, 2014.

[42] T. Ono and H. Takayanagi, "Osteoimmunology in bone fracture healing," Current Osteoporosis Reports, vol. 15, no. 4, pp. 367375, 2017.

[43] T. Wen and M. E. Rothenberg, "The regulatory function of eosinophils," Microbiology Spectrum, vol. 4, no. 5, 2016.

[44] H. Maazi, S. Shirinbak, N. Bloksma, M. C. Nawijn, and A. J. M. van Oosterhout, "Iron administration reduces airway hyperreactivity and eosinophilia in a mouse model of allergic asthma," Clinical \& Experimental Immunology, vol. 166, no. 1, pp. 80-86, 2011.

[45] E. P. Brigham, M. C. McCormack, C. M. Takemoto, and E. C. Matsui, "Iron status is associated with asthma and lung function in US women," PLoS ONE, vol. 10, no. 2, Article ID e0117545, 2015.

[46] N. V. Bhagavan and C. E. Ha, Essentials of Medical Biochemistry with Clinical Cases, Elsevier, USA, 2nd edition, 2015.

[47] A. Kovtun, S. Bergdolt, R. Wiegner, P. Radermacher, M. HuberLang, and A. Ignatius, "The crucial role of neutrophil granulocytes in bone fracture healing," European Cells and Materials, vol. 32, pp. 152-162, 2016.

[48] O. W. Bastian, L. Koenderman, J. Alblas, L. P. H. Leenen, and T. J. Blokhuis, "Neutrophils contribute to fracture healing by synthesizing fibronectin+ extracellular matrix rapidly after injury," Clinical Immunology, vol. 164, pp. 78-84, 2016.

[49] J. J. El-Jawhari, E. Jones, and P. V. Giannoudis, "The roles of immune cells in bone healing; what we know, do not know and future perspectives," Injury, vol. 47, no. 11, pp. 2399-2406, 2016.

[50] M. Croes, F. C. Öner, D. van Neerven et al., "Proinflammatory T cells and IL-17 stimulate osteoblast differentiation," Bone, vol. 84, pp. 262-270, 2016.

[51] I. Könnecke, A. Serra, T. El Khassawna et al., "T and B cells participate in bone repair by infiltrating the fracture callus in a two-wave fashion," Bone, vol. 64, pp. 155-165, 2014.

[52] T. Ono, K. Okamoto, T. Nakashima et al., "IL-17-producing $\gamma \delta$ T cells enhance bone regeneration," Nature Communications, vol. 7, no. 1, Article ID 10929, 2016. 
[53] A. Schindeler, M. M. McDonald, P. Bokko, and D. G. Little, "Bone remodeling during fracture repair: The cellular picture," Seminars in Cell \& Developmental Biology, vol. 19, no. 5, pp. 459466, 2008.

[54] B. Linke, Y. Schreiber, B. Picard-Willems et al., "Activated platelets induced an anti-inflammatory response of monocytes/macrophages through cross-regulation of $\mathrm{PGE}_{2}$ and cytokines," Mediators of Inflammation, vol. 2017, Article ID 1463216, 14 pages, 2017.

[55] I. Theurl, I. Hilgendorf, M. Nairz et al., "On-demand erythrocyte disposal and iron recycling requires transient macrophages in the liver," Nature Medicine, vol. 22, no. 8, pp. 945-951, 2016.

[56] H. Kudo, S. Suzuki, A. Watanabe, H. Kikuchi, S. Sassa, and S. Sakamoto, "Effects of colloidal iron overload on renal and hepatic siderosis and the femur in male rats," Toxicology, vol. 246, no. 2-3, pp. 143-147, 2008.

[57] E. S. Marks, M. L. Bonnemaison, S. K. Brusnahan et al., "Renal iron accumulation occurs in lupus nephritis and iron chelation delays the onset of albuminuria," Scientific Reports, vol. 7, no. 1, Article ID 12821, 2017.

[58] S. Nakatani, A. Nakatani, E. Ishimura et al., "Urinary iron excretion is associated with urinary full-length megalin and renal oxidative stress in chronic kidney disease," Kidney and Blood Pressure Research, vol. 43, no. 2, pp. 458-470, 2018.

[59] J. R. Connor, X. Zhang, A. M. Nixon, B. Webb, and J. R. Perno, "Comparative evaluation of nephrotoxicity and management by macrophages of intravenous pharmaceutical iron formulations," PLoS ONE, vol. 10, no. 5, Article ID e0125272, 2015.

[60] E. Lukaszyk, M. Lukaszyk, E. Koc-Zorawska, A. BodzentaLukaszyk, and J. Malyszko, "Fibroblast growth factor 23, iron \& inflammation -Are they related in early stages of chronic kidney disease?" Archives of Medical Science, vol. 13, no. 4, pp. 845-850, 2017.

[61] K. Wei, Z. Yin, and Y. Xie, "Roles of the kidney in the formation, remodeling and repair of bone," Journal of Nephrology, vol. 29, no. 3, pp. 349-357, 2016.

[62] A. E. Hassan, E. A. Shaat, M. M. Deif, N. M. El Azhary, and E. M. Omar, "Effect of erythropoietin hormone supplementation on renal functions and the level of hypoxia-inducible factor- $1 \alpha$ in rat kidneys with experimentally induced diabetic nephropathy," Alexandria Journal of Medicine, vol. 50, no. 1, pp. 69-75, 2014.

[63] M. Aghighi, M. M. Mazdeh, M. Nafar, and V. Rakhshan, "Factors associated with lumbar and femoral bone mineral density in kidney transplants candidates," Iranian Journal of Kidney Diseases, vol. 11, no. 5, pp. 379-384, 2017.

[64] J. H. Huh, S. I. Choi, J. S. Lim, C. H. Chung, J. Y. Shin, and M. Y. Lee, "Lower serum creatinine is associated with low bone mineral density in subjects without overt nephropathy," PLoS ONE, vol. 10, no. 7, Article ID e0133062, 2015. 


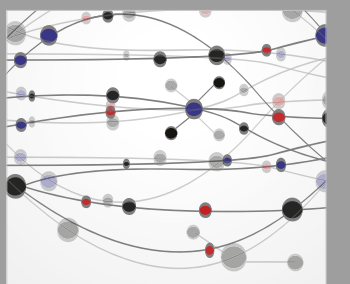

The Scientific World Journal
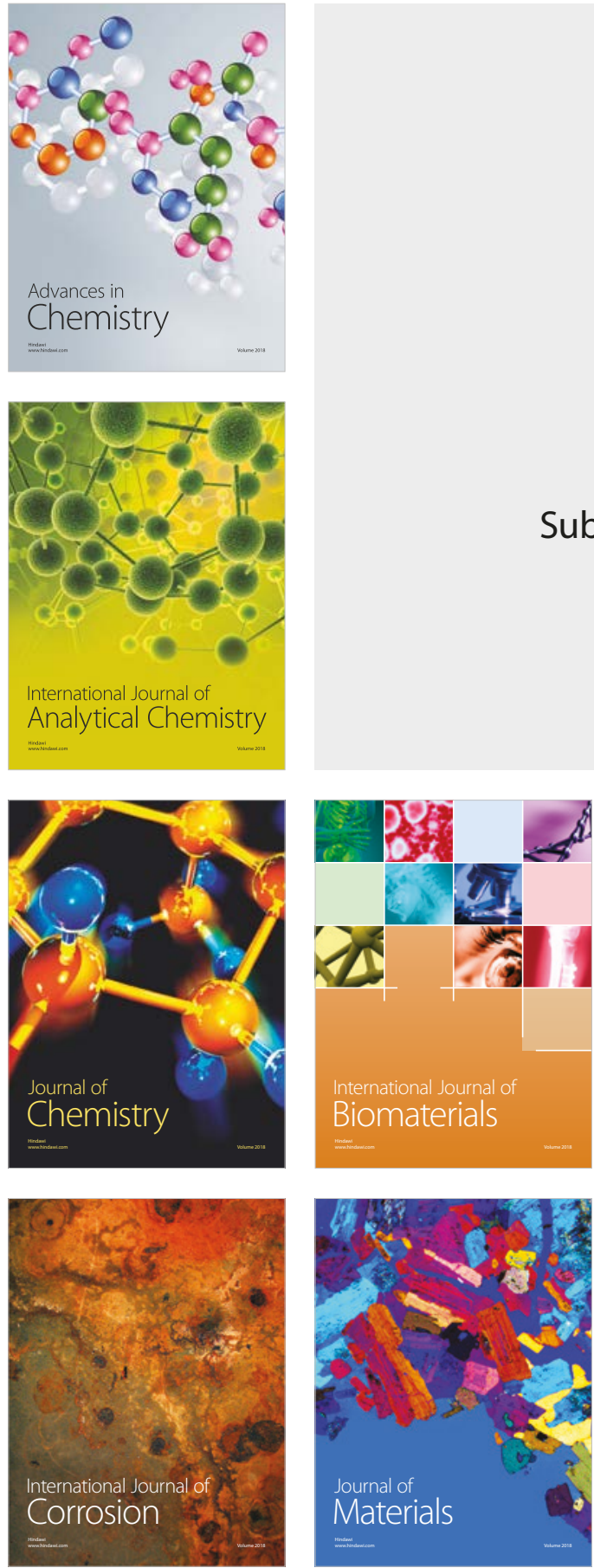

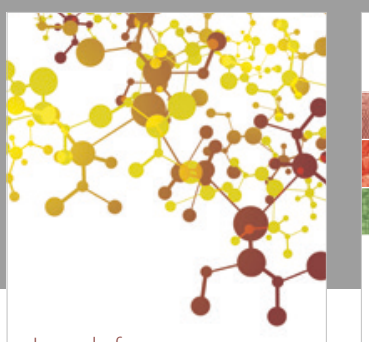

Journal of

Applied Chemistry
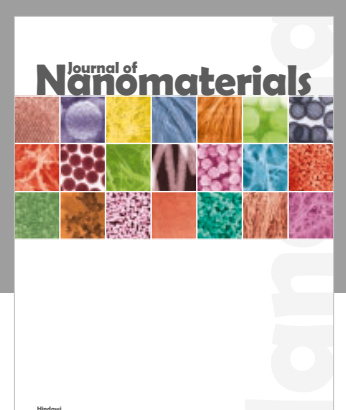

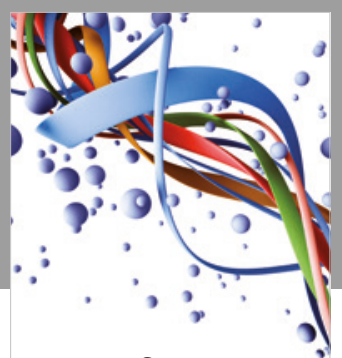

Scientifica

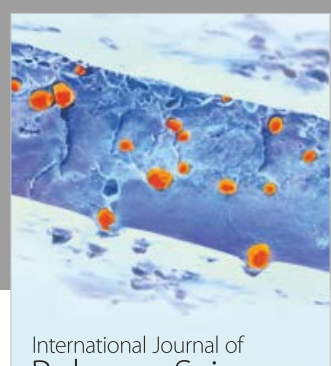

Polymer Science

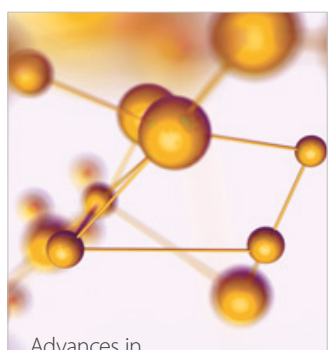

Physical Chemistry
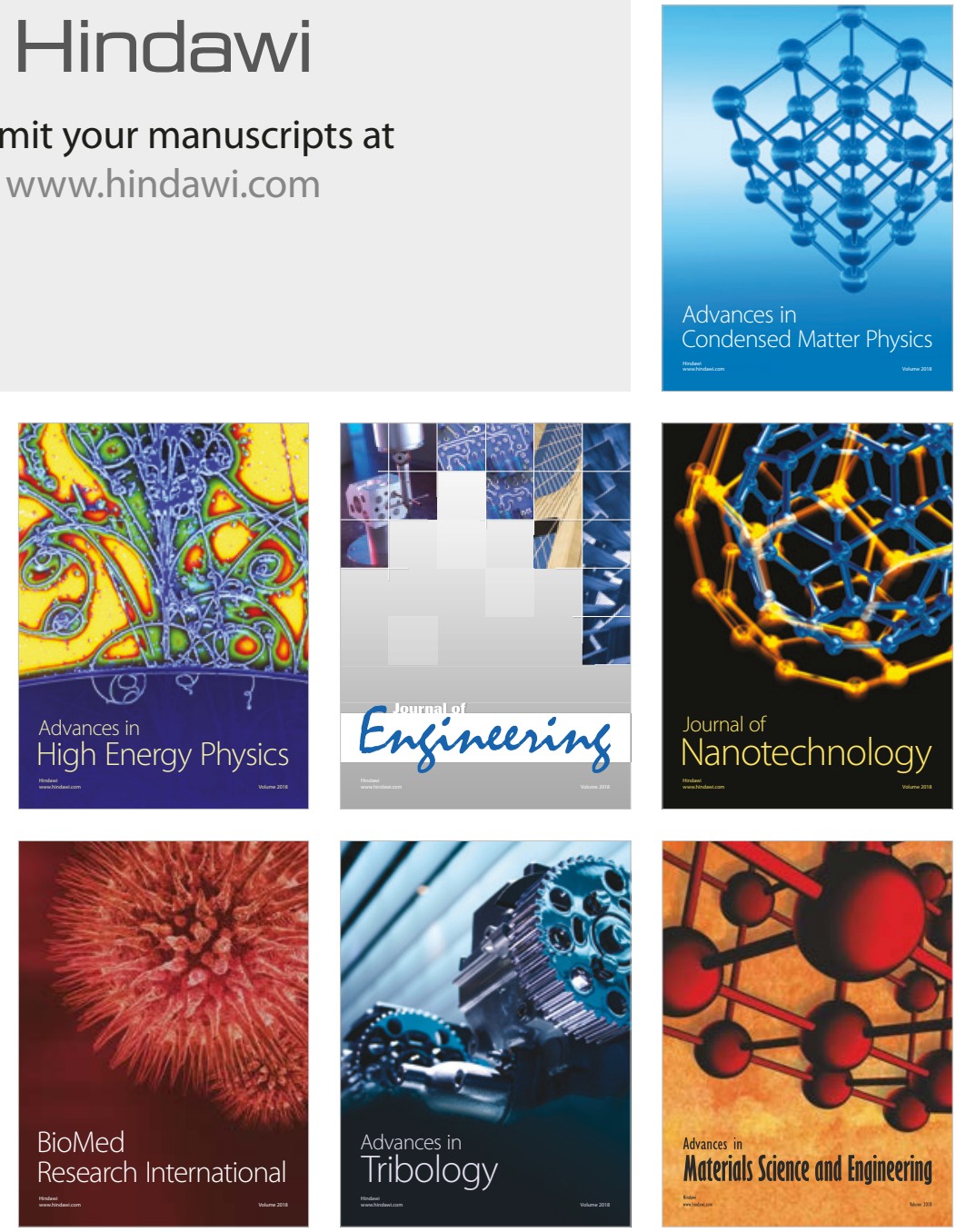